Kalpa Publications in Engineering
Volume 1, 2017, Pages 381-386
$\begin{aligned} & \text { ICRISET2017. International Conference on Re- } \\ & \text { search and Innovations in Science, Engineering } \\ & \text { \&Technology. Selected Papers in Engineering }\end{aligned}$

\title{
Algae Biodiesel: A Futuristic Fuel for Power Generation and for Automobile Industries
}

\author{
Alpesh Mehta ${ }^{1 *}$, Dr. Nirvesh Mehta ${ }^{2}$ \\ ${ }^{1}$ Research Scholar, Faculty of Engineering, R K University, Rajkot, Gujarat, India, \\ Assistant Professor, GEC Godhra, Gujarat, India. \\ ${ }^{2}$ Professor, Mechanical Engineering Department, LDRP-ITR, Gandhinagar, Gujarat, India \\ avmehta2002@gmail.com
}

\begin{abstract}
Need of energy is constantly increasing because of increase in population and industrialization globally. Depletion of fossil fuel, increase in pollution level and imbalance in the ecological level of the earth, etc. cause researcher to think for alternative solution of fossil fuel. Biodiesel derived from crops may be replacement of petroleum-derived fuel used for transport and power generation without adversely affecting the crisis of food and also keeping the environment clean. This research paper talks about algae cultivation, process for algae to biofuel conversion, conceptual design and general layout of slow pyrolysis process. B40 gives approximate 54\% mechanical efficiency compared to B0 of 51\% in an I.C.Engine. Thus, algae biodiesel may address current burning issues of the country as well as of the earth like global warming, treatment of sanitation/waste water, carbon sequestrations, rural development via creating lots of employment, etc
\end{abstract}

\section{Introduction}

Energy in its various forms are essential for survival and for better living standard. The industrial development and economic growth of any country is largely depending upon consumption of fossil fuels [01-10].The products of crude content gasoline, petrol, furnace oil, diesel,coal, natural gases etc. Fossil fuels are limited in amount, major cause of pollution and are depleting continuously. Indian economy is a DIESEL DRIVEN and hence fluctuation in the crude prices may cause unexpected changes in the various commodity prices. This research paper is focused on blending of replacement of fuel (diesel) used for power generation and for vehicles. The output of fossil fuel is exhaust gases that are liable for harmful effects on land, plants, animal and human lives. They are playing a major role in the ecological imbalance of earth and in global warming. So one has to think for a new source of energy, which is not only potential alternatives for fossil fuels, but also eco-friendly [01-20]. 


\section{About Algae}

Alga (or its plural, algae) is a single cellular plant, can grow large in amount, worldwide available can be easily converted into biodiesel for as a fuel for vehicles and for power generation. Refer Table 1[1-15]. Algae grow naturally in the entire world. For the algae cultivation and growth, land (waste/rocky), sufficient amount of solar radiation (minimum 07-08 hours per day), water (any one from drinkable/saline/blackish and carbon dioxide, nutrients like sulphur, phosphorus etc. are required in ample amount [01-20].

\begin{tabular}{|l|l|}
\hline First generation : & Biodiesel from Vegetable oil, Ethanol from Grains and sugar \\
\hline Second Generation: & $\begin{array}{l}\text { Lignocellulose to Diesel, Lignocellulose to Alcohols, } \\
\text { Vegetable oils to Diesel. }\end{array}$ \\
\hline Third generation: & Algal Oil/ Biodiesel, Algal Hydrogen, Biomass to Hydrogen. \\
\hline
\end{tabular}

Compare to all other sources of renewable energy sources like energy from biogas, wind energy, tidal energy, solar energy, geothermal energy, hydro energy etc. algae biodiesel has proved its importance by considering following factors;

a) non-conventional source of energy, eco-friendly, b)worldwide available, c)not a food in India, d)for the algae cultivation and growth, waste land, sufficient amount of solar radiation (07-08 hours per day), water drinkable /saline /blackish) carbon dioxide, and nutrients are required, e) mature within 18 to 20 hours (daily production is possible for fuel), f) blending is possible with existing fossil fuel/ diesel, g) no/ less pollutant, little emission of SOx and NOx, h)its co products / process outputs are mainly biochar and glycerol. Biochar can be used as animal feed, seeds for poultry farms, or can be used as fuel pallets for production of biogas, etc. [1-20].Table 2 represents the comparison of algae $\mathrm{v} / \mathrm{s}$ other crops for production of biodiesel.

\begin{tabular}{|c|c|c|}
\hline Crop & $\begin{array}{c}\text { Oil yield } \\
\text { (L/ha per year) (approximate) }\end{array}$ & $\begin{array}{c}\text { Land area needed } \\
\text { (M ha) (approximate) }\end{array}$ \\
\hline Corn & 170 & 1545 \\
\hline Soybean & 443 & 600 \\
\hline Canola & 1184 & 220 \\
\hline Jetropha & 1901 & 140 \\
\hline Coconut & 2689 & 99 \\
\hline Oil palm & 5942 & 46 \\
\hline Microalgae & 137007 & 2.2 \\
\hline
\end{tabular}

Table 2: Comparisons of Different Crops ${ }^{[5]}$

\section{Collection of Algae}

The initial task is to collect the algae. Open pond algae cultivation method is employed and the algae samples were collected from the river Misri near Shahera, Mahi river near Godhra, algae from wastewater available near Bhuravav, Godhra and algae from sewage water near Panchmahal Dairy Godhra. The collected algae samples were washed dewatered and are dried using natural sunlight in the solar drier. The botanical name of the collected algae is found blue-green algae. Samples were sent in the laboratories for algae characterization. Results proved that algae could be used as a fuel for power generation and for automobiles. The second task is to obtain biofuel from the dry algae powder. Slow pyrolysis process is selected out of flash pyrolysis, fast pyrolysis and slow pyrolysis. 


\section{About Pyrolysis}

Pyrolysis is thermo-chemical decomposition of organic material at elevated temperatures in the absence of oxygen (or any halogen). This type of pyrolysis is generally used to produce biofuel and biochar through carbonization. In slow pyrolysis, the measured biomass is heated at low temperatures around $300^{\circ} \mathrm{C}$ over a long period of time (>55 minutes) to maximize char formation along-with the production of green crude [8-28]. The temperature range in this case is not more than $350^{\circ} \mathrm{C}$ due to selection of the process and the metallurgical constrains of material (borosilicate glass) used [11-25].

\section{General layout of pyrolyser}

The general layout of slow pyrolyser is shown in figure 1.The vessel containing known weight of dry algae powder is kept in the heating mantle. The heater is made ON and the temperature of the flask is increased. Set one fix temperature for one set of reading. The nitrogen gas of constant flow/ measured flow is allowed to flow through entire system to make the system oxygen-free. Because of heating, algae vapor along-with nitrogen gas start to leave the flask and flow through jacket condenser. In the condenser, water with known temperature is used as a cooling medium is and is allowed to flow at various temperatures. The hot fluid rejects heat to the water and green crude as a output product/condensate is available in the flask. The obtained green crude is allowed to pass through distilled filtration tower and biodiesel is collected.

The slow pyrolyser is designed and tested under various temperature ranges; various cooling water temperatures and results are recorded. They repeated five times and the average results are recorded in the tables. The obtained condensate is known as green crude. The obtained green crude has to pass through fraction distillation tower and biodiesel is obtained.

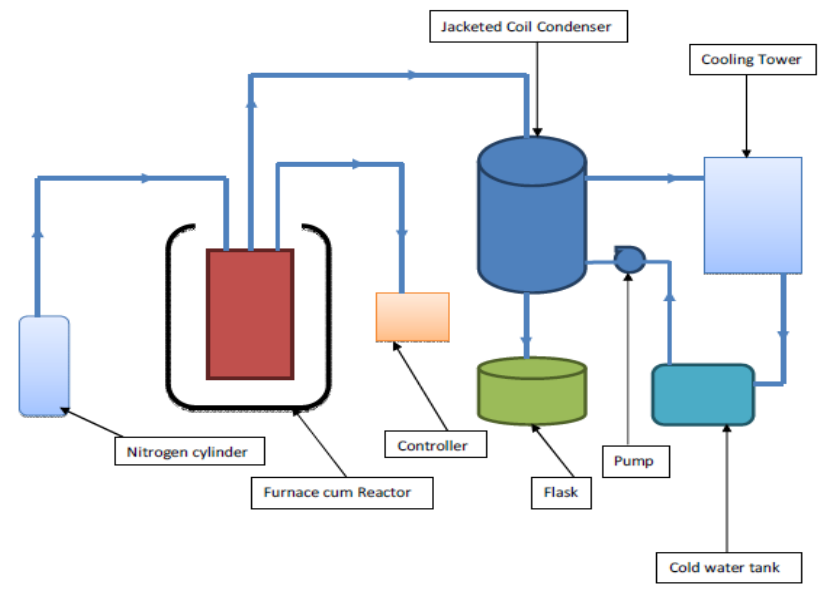

Figure 1: General layout of slow pyrolysis process

The obtained biodiesel may be directly use as a fuel for power generation and in automobiles. Various tests were carried in the laboratory on obtained algae biodiesel namely ultimate analysis, proximate analysis, LC-MS test, etc. and Exhaust gas analysis and results were obtained.

\section{Result and Discussion}

Comparision of obtained algae biodiesel with conventional diesel and with standard ASTM D6751 depicts the following[18-25]; the lowest temperature at which petroleum vapours will ignite under a low flame is known as flash point. It is important property for safe handling and storage of biodiesel. 
Flash point of algae biodiesel is $165{ }^{\circ} \mathrm{C}$ compared to $60^{\circ} \mathrm{C}$ of diesel. Hence algae biodiesel is nondangerous to handle and store as the flash point falls below $130^{\circ} \mathrm{C}$. Refer table 3 .

\begin{tabular}{|c|c|c|c|c|}
\hline \multirow[b]{2}{*}{ Parameter } & \multirow[b]{2}{*}{ Unit } & \multicolumn{3}{|c|}{ Specifications } \\
\hline & & $\begin{array}{l}\text { Biodiesel As Per } \\
\text { ASTM D } 6751\end{array}$ & $\begin{array}{l}\text { Biodiesel As } \\
\text { Per Lab. test }\end{array}$ & Diesel \\
\hline Flash Point & ${ }^{0} \mathrm{C}$ & Min.130 & 165 & 60 \\
\hline Density At $15^{\circ} \mathrm{C}$ & $\mathrm{Kg} / \mathrm{m}^{3}$ & $840-960$ & 878.088 & $\begin{array}{l}820- \\
860 \\
\end{array}$ \\
\hline $\begin{array}{c}\text { Kinematic } \\
\text { Viscosity@ } 40^{\circ} \mathrm{C}\end{array}$ & $\mathrm{mm}^{2} / \mathrm{sec}$ & $1.9-6.0$ & 2.11 & $2.5 .-6$ \\
\hline $\begin{array}{c}\text { Kinematic } \\
\text { Viscosity@ } 100^{\circ} \mathrm{C}\end{array}$ & $\mathrm{mm}^{2} / \mathrm{sec}$ & ---- & 0.52 & ----- \\
\hline Acid Number & $\mathrm{mg} \mathrm{KOH} / \mathrm{gm}$ & Max. 0.8 & 0.46 & Max. 0.5 \\
\hline $\begin{array}{c}\text { Copper Strip } \\
\text { Corrosion }\end{array}$ & $\mathrm{NO}$ & No.3 max & 2 & \\
\hline Cetane Number & ---- & Min.47 & 58 & Min.46 \\
\hline Ash Content & $\%$ & $0.01-0.10$ & 0.025 & 0.04 \\
\hline Total Glycerine & $\%$ & 0.240 & 0.21 & Max.0.25 \\
\hline Phosphorus Content & ppm & 10 & 7 & \\
\hline $\begin{array}{l}\text { Carbon Residue } \\
100 \% \text { Sample }\end{array}$ & $\%$ & $\operatorname{Max} 0.050$ & 0.028 & 12 \\
\hline $\begin{array}{c}\text { Fixed Carbon } \\
\text { Percentage }\end{array}$ & $\%$ & ---- & 73.42 & \\
\hline Water Content & $\mathrm{mg} / \mathrm{kg}$ & ---- & 834 & Max.500 \\
\hline Sediments Contents & $\%$ & $\begin{array}{ll}--- \\
\end{array}$ & 1193 & \\
\hline Sulphur Content & $\mathrm{ppm}$ & $\begin{array}{ll}--- \\
\end{array}$ & 14 & 330 \\
\hline Material Assay & $\%$ & $\begin{array}{ll}--- \\
\end{array}$ & 97 & \\
\hline Fire Point & ${ }^{0} \mathrm{C}$ & $\begin{array}{ll}--- \\
\end{array}$ & 235 & \\
\hline Net Calorific Value & $\mathrm{MJ} / \mathrm{KG}$ & ---- & 41.13 & $40-45$ \\
\hline Ethanol Content & $\mathrm{ppm}$ & $\begin{array}{cc}--- \\
\end{array}$ & 19 & Max. 2000 \\
\hline Methanol Content & $\%$ & $\begin{array}{ll}--- \\
\end{array}$ & 0.12 & Max. 0.20 \\
\hline Carbon Percentage & $\%$ & $\begin{array}{ll}--- \\
\end{array}$ & 78.42 & 85.7 \\
\hline Oxygen Percentage & $\%$ & $\begin{array}{ll}--- \\
\end{array}$ & 0 & $0.38-0.64$ \\
\hline Nitrogen Percentage & $\%$ & $\begin{array}{ll}--- \\
--1\end{array}$ & 0 & ---- \\
\hline
\end{tabular}

Table 3:Comparision of obtained biodiesel with astm D6751 $1^{[18-25]}$

Water and sediment is a measure of cleanliness of the fuel and also it is important in storage point of view. The value is $874 \mathrm{mg} / \mathrm{kg}$ in our case which is more than diesel. Copper strip corrosion test represent corrosiveness of biodiesel to copper or bronze cause sediment to form. The obtained biodiesel is very less corrosive to the various parts. Cetane number: It is a measure of how easily the fuel will ignite in the engine. Cetane number for algae biodiesel is 58 which is much more than diesel (46). This indicates that algae biodiesel may ignite easily and cause minimum chance of knocking in CI Engine. Ash content: It is measure of amount of suspended solids and soluble organometallic compounds contained by the fuel which may cause damage to fuel injection system, and abrasive wear on engine components (piston rings). The ash content in the obtained biodiesel is much less; hence it may be better replacement of conventional fuel.

Table 4 indicates exhaust gas analysis of obtained algae biodiesel and its comparison with Indian emission standards (BS-IV) with effective from 2011. The analysis indicates the exhaust gases 
contain carbon monoxide, nitrogen oxides and particulate matters which are in the range of Bharat Standards- IV.

\begin{tabular}{|c|c|c|}
\hline Parameter & $\begin{array}{c}\text { Obtained biodiesel } \\
\text { (gram/kilometer) }\end{array}$ & $\begin{array}{c}\text { Diesel emission norms } \\
\text { BS-IV (gram/kilometer) } \\
\text { w.e.f. 2011 }\end{array}$ \\
\hline Carbon Monoxide & 0.14 & 0.5 \\
\hline Nitrogen Oxides & 0.046 & 0.25 \\
\hline HC + NOx & 0.046 & 0.30 \\
\hline Particulate Matter & 0.022 & 0.025 \\
\hline HC & 0.00 & 0.08 \\
\hline
\end{tabular}

Table 4: Algae biodiesel- Exhaust gas analysis and comparision with BS-IV ${ }^{[18-25]}$

Hence it can be used as a fuel (pure/ blended) for power generation and also for automobile industries. The obtained biodiesel is tested with B0, B20 and at B40 in single cylinder four stroke diesel engine at LDRP-ITR with varying \% blending, compression ratio, injection pressure and engine load. The observations were recorded and based on that it is observed that at full load, B40 (algae biodiesel is blended $40 \%$ ) gave approximate 54\% mechanical efficiency compared with engine with diesel (B0) of $51 \%$ with compression ratio of 16 and with full load $(11 \mathrm{~kg})$.

\section{Conclusion}

Slow pyrolysis process eliminates one step i.e. algae to oil extraction compared to the other techniques. Algae biodiesel and bio-char are two main products at end of all processes. The obtained biofuel is tested in the laboratory and the properties are compared with the conventional transportation fuel-diesel. It is also compared with ASTM D6751 and find suitable for diesel-operated engines. It is also satisfy BS-IV emission standards as shown in table 3 and 4. Hence, algae biodiesel production will boost Industrial development, reduces unemployment, minimize GHG emission and help in achieving ecological equilibrium of the earth.

\section{References}

Jigisha Parikh, S.A. Channiwala, G.K. Ghosal, ' A Correlation For Calculating HHV From Proximate Analysis Of Solid Fuels', Fuel 84 ,2005, pp487-494.

M. Kumar, M. P. Sharma and G. Dwivedi, 'Algae Oil as a Future Energy Source in Indian Perspective', published in international journal of renewable energy research, vol. 3, no. 4, (2013), pp. 913-921.

Basak Burcu UZUN, 'Pyrolysis: A sustainable way from Waste to Energy', Anadolu University, Turkey.

Catie Ryan, Cultivating Clean Energy: The Promise of Algae Biofuels, Report to NRDC, USA, October 2009.

Tony Bridgwater, Elma Gyftopoulou, 'FAST PYROLYSIS OF BIOMASS: Technology and applications', presentation at Aston University Bio-Energy Research group, Brimingham, UK.

Philip T. Pienkos, The Potential for Biofuels from Algae, A presentation at Algae Biomass Summit, San Fransisco, CA, $15^{\text {th }}$ November,2007.

T.J.Lundquist, I.C.Woertz, et al., 'A Realistic Technology and Engineering Assessment of Algae 
Biofuel Production, Energy Biosciences Institute', University of California, Berkeley, California, October 2010.

Chanakya H.N., Mahapatra et al., 'Sustainability of Large-Scale Algal Biofuel Production in India ', in Journal of the Indian Institute of Science-A Multidisciplinary Reviews Journal, ISSN: 0970-4140 , VOL 92:1, Jan.-Mar. 2012.

Singh Jasvinder, Sai Gu , ' Commercialization Potential of Microalgae for Biofuels' Production Renewable and Sustainable Energy Reviews ,Vol.14 2010 ,pp-2596-2610.

J. Van Gerpen, B. Shanks, et al., Subcontractor report on Biodiesel Analytical Methods, August 2002-January 2004, NREL, Office of Energy Efficiency and Renewable Energy by Midwest Research Institute .

Sayadi M.H., Ghatnekar S.D., Kavian M.F., 'Algae a promising alternative for biofuel', at International Academy of Ecology and Environmental Sciences, 2011, 1(2), pp-112-124.

Rajvanshi Shalini, Mahendra Pal,'Microalgae: A Potential Source of Biodiesel', Journal of Sustainable Bioenergy Systems, 2012, 2, 49-59.

Bajhaiya A. K., Mandotra S.K, et al.,'Algal Biodiesel: the next generation biofuel for India', Asian J. Exp. Biol. Sci. Vol 1 (4), 2010, 729-739.

David Chiaramontia, Anja Oasmaab,Yrjo Solantaustab , 'Power generation using fast pyrolysis liquids from biomass', paper in Renewable and Sustainable Energy, article is in press.

Mary Solecki, Anisa Dougherty, Bob Epstein, Advanced Biofuel Market Report 2012- Meeting U.S. Fuel Standards, USA, 2012.

Ferrell John, Valerie Sarisky-Reed, National Algal Biofuels Technology Roadmap Workshop and Roadmap sponsored by the U.S. Department of Energy Office of Energy Efficiency and Renewable Energy Office of the Biomass Program Publication Date: May 2010.

Kelsi Bracmort, A Report on Algae's Potential as a Transportation Biofuel at Congressional Research Service, April 1, 2013.

Al Darzins and Philip Pienkos, Algae as a Feedstock for Biofuels -An Assessment of the Current Status and Potential for Algal Biofuels Production, NREL, US, July, 2011.

Yue Wang, a master's thesis on 'Microalgae as the third generation Biofuel: Production, Usage, Challenges and Prospects' submitted at Uppsala University, Uppsala, 2013.

Daniel Chaumont, 'Biotechnology of algal biomass production: a review of systems for outdoor mass culture', Journal of Applied Phycology 5: 593-604, 1993.

Liam Brennan A, Philip Owende, 'Biofuels from microalgae-A review of technologies for production, processing, and extractions of biofuels and co-products, Renewable and Sustainable Energy Reviews 2009, Paper in press.

Bryan H. Farrish,' Method and apparatus for upflow algae scrubber, macroalgal photobioreactor, US20130233779, US Patent, Sept 2013.

J. Van Gerpen, B. Shanks, and R. Pruszko, 'Biodiesel Production Technology' a technical report submitted to NREL, USA, 2002-2004.

Technical Information ASTM D975 Diesel Fuel Specification Test, Syntek Global Inc. Draper, UT 84020

http://indiatoday.intoday.in/education/story/leap- in- bharat- stage- standards/1/564736.html

'All you need to know about India's BS-IV and BS-VI emission norms' article published in the India Today, 06/01/2016.

Sudheer Pal Singh,' Decoding emission norms', article published in the Business Standard News on $18 / 01 / 2016$.

The Automotive Research Association of India (ARAI), 'INDIAN EMISSIONS REGULATIONS', December 2011.

'Emission Regulations', an article available on http://www.cumminsindia.com/ CFSI/ cummins_emission_info.html, 12 October 2015. 